\title{
Evaluation of the organizational and technical level of a company transitioning into the sixth innovation mode
}

\author{
Valery Maslennikov ${ }^{1}$, and Karina Chernitsova ${ }^{1,{ }^{*}}$ \\ ${ }^{1}$ Department of Theory of Management and Business Technologies, Plekhanov Russian University of \\ Economics in Moscow, Moscow, Russia
}

\begin{abstract}
Relevance - during the transition to the sixth technological order, the importance of quantitative evaluating company's organizational and technical level rises, along with prospects for its improvement through innovation. The goal - examining the existing approaches to evaluating the organizational and technological level of companies in the high-tech business sector, and propose possible approaches to creating a dynamic real-time assessment of the named level. Methods - a comparative analysis was carried out of the approaches employed in the quantitative evaluation of a company's organizational and technical level in terms of their compliance with the transition to the sixth technological order. Results the study showed that evaluating the technical level of high-tech companies is possible based on information about the influence of factors that can be grouped into three categories: technical, economic and organizational factors. Conclusions: It was established that the developed method allows identifying a company's technical level, assessing a company's competitiveness and formulating a strategy for production development.
\end{abstract}

\section{Introduction}

Assessing the impact of innovation on the technological level is viewed from different perspectives. The focus is placed on the differences of innovation in large, medium and small enterprises [1 - 2]. On an equal basis, universities are considered as a source of innovation for technology development [3 - 6].

That said, it has been proven [7] that the patents and technology resulting from research activities do not fully reflect the needs of enterprises in technological development. A similar position is held by other researchers in innovation [8-16]. This is due to the fact that scientists' ideas about innovations are implemented in their understanding of research results, declare Dilek Karahoca and Ayça Kurnaz. In this light, it has also been proven that an intuitive perspective of the researchers with respect to their results always supports the quality of the results of innovation, and therefore, it is difficult to apply the results on the dissemination of innovation in industrial enterprises [17].

\footnotetext{
${ }^{*}$ Corresponding author: kalinina309@yandex.ru
} 
A company's organizational and technical level and staff training are profoundly interrelated processes. Therefore, the concept of structural training is needed for the organization of a continuous process of the reorganizing the existing technological level of production structures, while the availability of educational trajectories allows to transform challenges and shortcomings into opportunities [18].

The technological gap ultimately induces an increase in the inequality of individual industries occurs in many countries. An article by Fernando Perera-Tallo presents a model of growth in which technological changes lead to an increase in the share of enterprises income [19]. Cristiano Antonelli [20] determines the technological correspondence between the elasticity of production and costs, which is required to evaluate the technological level. Authors focusing on the wavelet transform [21] offer their own approaches to the macroeconomic methods of quantifying changes in the economy in terms of technological changes.

A review of the literature suggests that there are not enough publications to assess the technological level of enterprises, industries, regions and countries during the transition to the 6th technological mode, while poorly conceptualized and methodologically weak statistical base is provided.

In this paper, we investigate approaches to assessing the technological level and innovative activity of individual European countries; and it is shown that the current methodology does not fully fit for the microeconomic level, which is made up of industrial companies under the 6th technological mode.

Purpose of the study was to formulate the main approaches to the evaluation of the technological level of industrial companies for assessing the changes related to the implementation of innovative development strategies in the transition to the 6th technological mode.

The novelty of the work is to develop a methodology for assessing the state of the technological level of an enterprise in relation to the influence of the organization of management, taking into account the deterioration of equipment.

The study uses the available statistical data from the European Commission and the authors' results of studies conducted in high-tech sectors of the Russian Federation.

\section{Relevance of the research.}

The current level of the Russian economy is characterized by a decrease in production and technological capabilities. Over the last 8-10 years, there has been a four-fold reduction in production investment, resulting in the depreciation of fixed assets closer to $50 \%$; at the same time, the renewal coefficient was $3.4 \%$, thus predetermining Russia's technological backwardness. The average age of equipment exceeded 20-30 years, i.e. twice as much as in the developed countries, which was one of the reasons for the rapid degradation of the country's technological structure.

The technological gap is also associated with a low-cost expenditure, implemented by Russian companies on research and development: on average, $65 \%$ of them spend more in this area of less than $1 \%$ of their turnover. In this case, the structure of expenditure on technological innovation is dominated by market research and industrial design (50\%).

At the same time, the transition to the 6th technological system requires launching sectors of higher technological redistribution (mechanical engineering, chemical and petrochemical complexes). Today, Russia's industrial policy strategy should be based on investment and technological development, which will see the emergence of new industry leaders at its core. These industries must ensure the progressive and rapid development of the national economy in the medium and long term.

Research methods: A comparative analysis of approaches to the quantitative evaluation 
of the organizational and technical level of companies in terms of their compliance with the transition to the sixth technological order.

Main part. Economic science still has not yet developed a solid understanding of the process of modernization based on the evaluation of the technological level, which is seen primarily as investments in R \& D and human capital.

To determine the technical and economic level of production in Russia and abroad, a number of techniques are used that allow to evaluate development of the country by implementing private and general indicators on technique indexes and indicators of competitiveness development - Growth Competitiveness Index (GCI) provided by the World Economic Forum in the Global Competitiveness Reports [22], as well as indices and indicators of the international rankings of the innovative activity of countries on the European Innovation Scoreboard (EIS), provided by the EU [23] (Table 1).

Table 1. Comparison of the ratings of the innovative and technological levels of countries occupying the first 10 places in the technological and innovation level rankings

\begin{tabular}{|c|c|c|c|c|c|c|}
\hline \multirow{2}{*}{ Country } & \multicolumn{2}{|c|}{$\begin{array}{l}\text { Availability of latest } \\
\text { technologies }\end{array}$} & \multicolumn{2}{|c|}{$\begin{array}{c}\text { European Innovation } \\
\text { Scoreboard }\end{array}$} & \multirow{2}{*}{$\begin{array}{l}\text { Discrepancies } \\
\text { in normalized } \\
\text { estimates }\end{array}$} & \multirow{2}{*}{ Place } \\
\hline & Value & $\begin{array}{l}\text { Normalized } \\
\text { estimate }\end{array}$ & Value & $\begin{array}{c}\text { Normalized } \\
\text { estimate }\end{array}$ & & \\
\hline 1 & 2 & 3 & 4 & 5 & 6 & 7 \\
\hline Switzerland & 5,8 & 1 & 0,79139 & 1 & 0 & 1 \\
\hline Sweden & 5,4 & 0,931034483 & 0,70398 & 0,889548769 & 0,041485714 & 3 \\
\hline Denmark & 5,3 & 0,913793103 & 0,70027 & 0,884860815 & 0,028932289 & 2 \\
\hline Finland & 5,5 & 0,948275862 & 0,6494 & 0,820581508 & 0,127694354 & 5 \\
\hline Germany & 5,5 & 0,948275862 & 0,63155 & 0,798026258 & 0,150249604 & 8 \\
\hline Netherlands & 5,5 & 0,948275862 & 0,6315 & 0,797963078 & 0,150312784 & 9 \\
\hline Ireland & 5,1 & 0,879310345 & 0,60854 & 0,768950833 & 0,110359511 & 4 \\
\hline Belgium & 5,2 & 0,896551724 & 0,60211 & 0,760825889 & 0,135725836 & 6 \\
\hline United Kingdom & 5,4 & 0,931034483 & 0,60177 & 0,760396265 & 0,170638218 & 10 \\
\hline Luxembourg & 5,2 & 0,896551724 & 0,59824 & 0,755935759 & 0,140615966 & 7 \\
\hline
\end{tabular}

In 2016, Switzerland occupied the first five places in the ranking $(0,79139)$, Sweden $(0,70398)$, Denmark $(0,70027)$, Finland $(0,6494)$ and Germany $(0,63155)$.

A comparison of the estimates of the innovation and technological levels of the countries occupying the first 10 places in the technological and innovation level rankings shows that the direct connection between innovative activity and technological level is characteristic only for the leading countries that rank first in the discrepancy between the normalized estimates.

For other countries, such a relationship is not detected, indicating a multidirectional change dynamic at the micro-level.

The following indicators are used as change indicators on the macro-economic level:

- the share of innovation-active enterprises in the total number of organizations,

- the share of innovative products in the total output,

- the share of expenditure on research and development in relation to the volume of product output (research intensity).

At the same time, the 2016 European Innovation Scoreboard does not provide the assessments of the levels of technological innovation for the development of innovative strategies at the enterprise level of individual industries that are united by a common technology platform.

The technological level of industry enterprises depends on their innovation strategy, and is largely determined by the investment firms in their own research and development as well as their effectiveness. This connection determines the technological modernization of the material and technical bases of industries. 
The study showed that the technological levels of high-tech enterprises should be considered as the ability of a technical subsystem to work in a fault-free operation with a given range of parameters under the influence of disturbances on the quality of raw materials, etc.

On changing the processes being influenced by the innovation, a multivariate study is usually conducted, while selection of the best process is carried out at a minimum economic cost of the planned production output volume.

Based on the above, an innovation level determining a change in the technological processes is formed in the following composition:

1) organizational and technical level of production;

2) operations management level.

For any production unit, the composite index for the organizational and technical level of production is comparable, regardless of objects or the type and quality of the products, the applied technology, processes and their organization.

The composite index shows how much of the actual economic cost makes up the cost of manufacturing the same product in the same volume with the full use of the basic elements of production, i.e. without internal production loss of material and labor resources.

The reciprocal value indicates how much the actual economic cost of producing a specific product exceeds the necessary costs in the absence of losses, while the difference between the denominator and the numerator makes up the internal production reserves for their reduction.

The operations management level is a relative characteristic that allows evaluating how efficiently and fully the basic elements of production are used under the planned product output program and under the terms and conditions of existing and new technological levels.

In this case, the composite index of the efficiency of use of the main production process of the organizational and technical level of production and operational management for production under changing technological processes shall be determined ( $I_{O T}$ ):

$$
I_{O T}=\frac{C_{T_{\text {new }}}}{C_{T_{\text {actual }}}+\Delta C_{P L}+\Delta C_{O M}}
$$

$C_{T_{\text {new }}}$ and $C_{T_{\text {actual }}}$ - respectively, the specific economic costs of production without taking into account losses associated with the organization of the production process, i.e., when fully utilizing the equipment and working hours, RUR.,

$\Delta C_{P L}-$ additional costs associated with an increase in the technological level of production, RUR.;

$\Delta C_{O M}$ - additional costs associated with the operational management of the production of a new technological level, RUR..

In the company "Mechanical Engineering Technology" the production cost with full use of equipment and working time ( $C_{T_{\text {new }}}$ ) amounted to 150 million rubles in 2014.

As a result of increasing the technological level of production, the production cost with full use of equipment and working time $\left(C_{T_{\text {actual }}}\right)$ amounted to 200 million rubles in 2016 . This required additional costs associated with raising the technological level of production $\left(\Delta C_{P L}\right)$ in the amount 3 million rubles. Also, additional expenses related to the production operational management of a new technological level $\left(\Delta C_{O M}\right) 0.5$ million rubles were realized. 
As a result, the organizational and technical level of production and operational management was 0.737 in 2014-2016, which means lower production costs due to increased efficiency in the use of equipment, technology and operational management.

Evaluating the organizational and technical level is necessary for supplementing the monitoring of the physical deterioration of the equipment, as the new level of technology leads to the rapid development of resource capacity.

The selected equipment deterioration criteria are linearly independent and enable to comprehensively assess the development of equipment resources of innovation-active enterprises with respect to changes in the technological level.

The indicator weights are determined expertly based on the importance of a particular type of equipment for the entire production complex of the enterprise. Use of the following scale for rating the depreciation of equipment is proposed (Table 2).

The physical deterioration of the equipment as a whole is estimated based on the deterioration of a key element with a physical deterioration that is assigned the highest weight, for example, equal to 0.5. Knowing the other less significant elements of the equipment with physical deteriorations that affect the costs to a lesser extent, the weight may be calculated, for example, equal to 0.3 . The least expensive and relatively easy-toreplace elements of equipment may have a physical deterioration weight in the overall assessment of the physical deterioration, of, for example, equal to 0.1 .

Therefore, the integrated resource development index for the equipment when assessing an enterprise's technological level is calculated by the formula:

$$
R=0,5 K_{1}+0,3 K_{2}+0,1 K_{3},
$$

where $\mathrm{Ki}$ - development index of the $\mathrm{i}$-th equipment resource, selected for the rating; the integral index values range from 0 to 1 .

An estimation example of the equipment life-cycle integrated indicator for the key elements wear: it is required to determine the physical wear coefficient for the mechanical press. The annual depreciation rate for $\mathrm{A}=7.7 \%$. The chronological age is 12 years.

Table 2. Scale for assessing the physical deterioration of equipment

\begin{tabular}{|c|c|c|}
\hline $\begin{array}{l}\text { Depreciation } \\
\text { rate }\end{array}$ & $\begin{array}{l}\text { Equipment } \\
\text { condition }\end{array}$ & Description of equipment condition \\
\hline $0-5$ & New & $\begin{array}{c}\text { New, newly installed equipment still to be put into operation, } \\
\text { equipment in excellent condition }\end{array}$ \\
\hline $5-17$ & Very good & $\begin{array}{l}\text { Used equipment that has been completely repaired or restored, in } \\
\text { very good condition }\end{array}$ \\
\hline $17-33$ & Good & $\begin{array}{l}\text { Used equipment that has been completely repaired or restored, in } \\
\text { good condition }\end{array}$ \\
\hline $33-50$ & Normal & $\begin{array}{l}\text { Used equipment that is requiring some kind of repair or } \\
\text { replacement of individual small parts, such as bearings, brasses, etc. }\end{array}$ \\
\hline $50-67$ & $\begin{array}{l}\text { Relatively } \\
\text { usable }\end{array}$ & $\begin{array}{l}\text { Used equipment that is in a condition suitable for further work but } \\
\text { is requiring significant repair or replacement of major parts such as } \\
\text { the engine and other critical parts }\end{array}$ \\
\hline $67-83$ & Poor & $\begin{array}{l}\text { Used equipment that is requiring major repairs, such as replacing } \\
\text { the working bodies of basic units }\end{array}$ \\
\hline $83-95$ & Unusable & Used equipment that is unsuitable for further use \\
\hline$>95$ & Broken & $\begin{array}{l}\text { Equipment in respect of which there is no reasonable prospect of } \\
\text { resale, except for the cost of basic materials that can be extracted } \\
\text { from it }\end{array}$ \\
\hline
\end{tabular}

The equipment key elements were replaced in the seventh year of operation and accounted for $15 \%$ of the press components. Less significant elements of equipment $(25 \%$ of parts and assemblies) on the 9th year of operation have been replaced with new ones. 
Least expensive and relatively easily replaced equipment elements $(60 \%$ of parts and assemblies) were replaced by the 12 th year of the press operation.

Calculation:

1. Determine the press normative service life as a value opposite to the depreciation rate: $100 \% / 7.7=13$ years. Since the chronological age of the press is 12 years and no major repairs have been made, it can still remain in operation.

2. $15 \%$ of details and units have a chronological age: $12-7=5$ years and referred by experts to a good condition $(10 \%) ; \mathrm{K} 1=0.15 \times(1-0.1)=0.135$.

3. $25 \%$ of details and units have a chronological age: $12-9=3$ years and referred by experts to a satisfactory condition $(35 \%)$ : $\mathrm{K} 2=0.25 \times(1-0.35)=0.1625$

4. $60 \%(100 \%-15 \%-25 \%)$ of parts and assemblies have a chronological age: 12 years and are classified by experts as conditionally suitable $(60 \%)$ : $\mathrm{K} 3=0.60 \times(1-0.6)=0.24$.

5 . The resource development integral index of the mechanical press will be:

$\mathrm{R}=0.5 \times 5 \times \mathrm{K} 1+0.3 \times 3 \times \mathrm{K} 2+0.1 \times 12 \times \mathrm{K} 3=2.5 \times 0.135+0.9 \times 0.1625+7.2 \times 0.24=$ $0.3375+0.1463+1.728=2.218$ years.

6. The physical wear coefficient of the press will be: $1-2.2 / 13 \times 100 \%=83 \%$.

Thus, the mechanical press will be able to work without a noticeable loss of quality for 2.2 years of service, taking into account the resource consumption, provided the operation conditions are met by the recommended manufacturer, and the repair and maintenance work will be performed on time and qualitatively.

\section{Conclusion}

The advantage of the provisions put forward is the validity and reliability of the private and general indicators that are used to assess the organizational and technical level of production and their strict adherence to the essence of the more efficient use of production resources as a result of changes in the technological level of production.

In this system, there is a relationship between the current and non-recurring costs of producing goods. The system can be used not only as a means of analyzing, planning and controlling the organizational and technical level of production, but also as a means of research and involvement in the use of the existing reserves in production. The increasing of the production technological level is proposed to be evaluated taking into account the three groups of factors: technical, economic and organizational

1. Technical factors include:

- Development and application of modern production processes

- Application of advanced methods of processing parts

- The use of machines and equipment with modern means of active and objective quality control

- Application of an automated production management system

- Application of the computer-aided design (CAD) system for technological equipment

- Control automation over the network schedules implementation for the design and production of technological equipment

2. Economic factors are a phased advance financing of the work for "technological" production preparation, the creation of a stimulating fund for the new technology development (Start-up into production), etc.

3. Organizational factors - development and deepening of production specialization; certification of the technological process quality and manufacturing of technological equipment, improvement of the auxiliary production organization; improvement of the relationship between auxiliary and main production; expansion of intra-factory, intraindustry cooperation, etc. 


\section{References}

1. G. Ahuja, C. Morris Lampert, Strategic Management Journal, 22 (6-7), 521-543, (2001).

2. C. Corradini, P. Demirel, G. Battisti, Small Bus. Econ., 47, 163-177, (2016).

3. M. Guerzoni, T.T. Aldridge, D.B. Audretsch, S. Desai, Research Policy, 43 (10), 1697-1706, (2014).

4. Lissoni, F., Montobbio, F., Cahiers du GREThA, 2012-24. (Available at: http://cahiersdugretha.u-bordeaux4.fr/2012/2012-24.pdf, 2012)

5. A.M. Petruzelli, Technovation, 31 (7), 309-319, (2011).

6. V.V. Maslennikov, L.G. Skamaj, N.V. Kozlov, Setevoe vzaimodejstvie vuza, hozyajstvennyh obshchestv i vysokotekhnologichnyh predpriyatij. - Vestnik Universiteta (Gosudarstvennyj universitet upravleniya). № 26. p. 191-199, (2011).

7. Srecko Nesic, Ulrich Krupp, Wilhelm Michels. An Investigation on Configuration status of Science and Technology Resource in the Coal Industry of Heilongjiang Province Original Research Article Energy Procedia, Volume 5, Pages 2167-2171, (2011).

8. L. Fleming, O. Sorenson, Strategic Management Journal, 25, 909-928, (2004),

9. W.B. Arthur, Research Policy, 36 (2), 274-287, (2007).

10. S. Breschi, F. Lissoni, F. Malerba, Research Policy, 32 (1), 69-87, (2003).

11. M. Coffano, G. Tarasconi, Center for Research on Innovation, Organization and Strategy, CRIOS Working Paper n.1, (2014).

12. P. Criscuolo, B. Verspagen, Research Policy, 37 (10), 1892-1908, (2008).

13. A. Datta, L.M. Jessup, Technovation, 33 (10-11), 355-367, (2013).

14. M. Du Plessis, B. Van Looy, X. Song, T. Magerman, Data production methods for harmonized patent statistics: Patentee sector allocation, (Eurostat Working Paper-Annual Report, available at: http://ec.europa.eu/eurostat/documents/3888793/5835901/KS-AV-06-001-EN.PDF , 2010).

15. F. Malerba, M. Mancusi, F. Montobbio, Review of World Economics, 149 (4), 697 - 722 , (Available at: http://dx.doi.org/10.1007/s10290-013-0167-0, 2013),

16. J.M. Wooldridge. Econometric Analysis of Cross Section and Panel Data (second edition), (MIT Press, 2010).

17. Dilek Karahoca, Ayça Kurnaz, Procedia - Social and Behavioral Sciences, (131), 211-217, (2014).

18. Antonio Andreoni, Structural Change and Economic Dynamics, 29, 58-74 (2014).

19. F. Perera-Tallo, Journal of Macroeconomics, 52, 23-38, (2017).

20. C. Antonelli, Structural Change and Economic Dynamics, 38, 15-24, (2016).

21. F. de Melo, V.V. Maslennikov, E.V. Popova, T.L. Bezrukova, I.V. Kyksova, Asian Social Science, 11 (20), 66-73, (2015).

22. Global Competitiveness Report (Available at: http://reports.weforum.org/globalcompetitiveness-report-2015-2016/competitiveness-rankings/, Accesed martie 2017).

23. European Innovation Scoreboard (Available at: http://ec.europa.eu/growth/industry/innovation/facts-figures/scoreboards_en, Accesed martie 2017). 